\title{
The Bacteriophage $\lambda$ DNA Replication Protein P Inhibits the oriC DNA- and ATP-binding Functions of the DNA Replication Initiator Protein DnaA of Escherichia coli
}

\author{
Indrani Datta, Subrata Sau, Alok Kumar $\mathrm{Sil}^{\S}$ and Nitai C. Mandal* \\ Department of Biochemistry, Bose Institute, Acharya J. C. Bose Birth Centenary Building, P-1/12, CIT Scheme VII M, Kolkata 700054 \\ ${ }^{\S}$ Department of Microbiology, University College of Science, 35 Ballygunj Circular Road, Kolkata 700 019, India
}

Received 22 September 2004, Accepted 21 October 2004

\begin{abstract}
Under the condition of expression of $\lambda P$ protein at lethal level, the oriC DNA-binding activity is significantly affected in wild-type $E$. coli but not in the $r p l$ mutant. In purified system, the $\lambda P$ protein inhibits the binding of both oriC DNA and ATP to the wild-type DnaA protein but not to the $r p l$ DnaA protein. We conclude that the $\lambda \mathrm{P}$ protein inhibits the binding of oriC DNA and ATP to the wild-type DnaA protein, which causes the inhibition of host DNA synthesis initiation that ultimately leads to bacterial death. A possible beneficial effect of this interaction of $\lambda P$ protein with $E$. coli DNA initiator protein DnaA for phage DNA replication has been proposed.
\end{abstract}

Keywords: $d n a A$ gene of $E$. coli, Lambda $P$ gene, oriC DNA, $\lambda$ P-DnaA interaction, $\lambda P$ gene lethality

\section{Introduction}

Bacteriophages being obligate parasites exploit one or more of the gene functions of their host(s) for their own growth. Such exploitations imposed by the phages may be nonlethal or lethal to their host(s). The non-lethal interactions of bacteriophage $\lambda$ genes with those of Escherichia coli have been studied in depth (Friedman et al., 1984). These have been summarized in Datta et al. (2005) There are three reports of host toxicity by lambda. (1) Induction of $\lambda N^{\top} c \mathrm{I} t s$ lysogen at $42^{\circ} \mathrm{C}$ causes bacterial killing that requires the phage replication genes $O$ and $P$ as well as the right promoter $p \mathrm{R}$ (Sly et al., 1968). (2) The kil gene located between the $\gamma$ and $c$ III genes in the left operon of $\lambda$ has been reported to be lethal

*To whom correspondence should be addressed.

Tel: Fax: 91-33-2334-3886

E-mail: ncmandal@bic.boseinst.ernet.in or mandalnc2003@yahoo.com to $E$. coli (Greer, 1975a). The Kil protein possibly interacts with certain component (s) of the cell envelope (Greer, 1975b) and inhibits division (Sergueev et al., 2001) (3) The CII protein of this phage has been reported to inhibit host DNA replication (Kedzierska et al., 2003)

We showed for the first time that the DNA replication gene $P$ of $\lambda$ when expressed at elevated level caused bacterial killing even in the absence of phage DNA replication (Maiti $e t$ al., 1991a) and that the E. coli rpl mutants which were resistant to $\lambda \underline{P}$ gene lethality could be isolated by the mutagenesis of this bacterium (Maiti et al., 1991b), and also the rpl-like mutations have been isolated by in vitro mutagenesis of the dnaA gene is a plasmid (Datta et al., 2005). All those $r p l$ mutations have been located within the bacterial DNA initiator gene dnaA (Datta et al., 2005). All these suggest that the $\lambda P$ gene-mediated host lethality possibly involves its certain type of interaction with the DnaA protein (the DnaA protein will be called as DnaA in the text) of $E$. coli. In this paper we show by using purified proteins that the oriC DNA and ATP binding functions of DnaA are inhibited by the $\lambda \mathrm{P}$ protein (the $\lambda \mathrm{P}$ protein will be called as $\mathrm{P}$ in the text).

\section{Materials and Methods}

Media, bacterial and bacteriophage strains and growth conditions and DNA isolation The compositions of tryptone broth (TB), tryptone broth with maltose (TBM), and tryptone agar and soft agar are described in Chattopadhyay and Mandal (1982), and those of Luria-Bertani (LB) broth in Sambrook et al. (1989). E. coli DH5 (endI ${ }^{-}{ }^{-} \mathrm{m}^{+}$suII $\mathrm{I}^{+}$thi recA $\mathrm{gyr}^{-}$rel) was obtained from S.

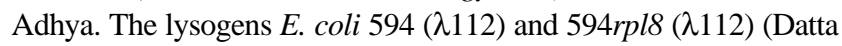
et al., 2004) and $\lambda N^{-} c I^{-} h k$ phage (Maiti et al., 1991a) were used from laboratory stocks.

E. coli cultures were routinely grown in TB, TBM (for $\lambda$ infection experiments) or $\mathrm{LB}$ at $37^{\circ} \mathrm{C}$ with shaking, and the growth 
was monitored by measuring the OD of the culture at $590 \mathrm{~nm}$. The bacteria harboring plasmid were grown in the presence of required antibiotic. Bacteriophage $\lambda$ was prepared by growth and lysis in permissive E. coli in TBM. Plasmid DNA was isolated by the procedure as described (Sambrook et al., 1989). The plasmid pTSO200 DNA (Oka et al., 1980) was labeled with $\left[{ }^{3} \mathrm{H}\right]$ by growing the bacteria (harboring pTSO200) for $16 \mathrm{~h}$ in the the presence of $\mathrm{Cm}(15 \mu \mathrm{g} / \mathrm{ml}),\left[{ }^{3} \mathrm{H}\right]$-thymidine $(1 \mu \mathrm{Ci} / \mathrm{ml}, 17.2 \mathrm{Ci} /$ mmol) and 2-deoxyadenosine $(250 \mu \mathrm{g} / \mathrm{ml})$ in $\mathrm{TB}$, and then the plasmid DNA was isolated.

Plasmids Recombinant DNA methods used were as described in Sambrook et al. (1989). The plasmid pALO12 contains the wildtype $d_{n a A}$ gene tagged to the lacP promoter (Lobner-Olesen $e t$ al., 1989). The plasmid pTSO200 (Oka et al., 1980) contains the minimal 245 base pair (bp) oriC DNA sequence of E. coli. pSP562 (obtained from D. Chattoraj, NIH, USA) contains the wild-type $d n a B$ gene of $E$. coli tagged to the $p \mathrm{~L}$ promoter. The plasmid pMM3 is a cro- $t \mathrm{R} 1-c \mathrm{II}-O$ deletion derivative of pMR45 (Fig. 1, Maiti et al., 1991a). In the absence of cro and $t \mathrm{R} 1$, this plasmid expresses the $P$ gene at an elevated level from the $p \mathrm{R}$ promoter in the absence of $\lambda$ repressor. pDM1 (Fig. 1) is a $\lambda p L$-based expression plasmid and was made as follows: the $1.2 \mathrm{~kb}$ DNA segment flanked by the BamHI site at the left of $N$ and the BglII site at the left of $c$ I was gel purified and ligated with BamHI-digested $4.36 \mathrm{~kb}$ pBR322 DNA. The ligated plasmid pDM1 (5.56 kb) was selected by its Tet sensitivity and Amp resistance. Any gene cloned at the Bam $\mathrm{HI}$ site in the direction of $p \mathrm{~L}$ promoter would be expressed in the absence of $\lambda$ repressor. pDM2 (Fig. 1) was constructed by ligating the gel-purified BamHI $1.5 \mathrm{~kb}$ DNA segment containing the wild-type dnaA gene from pLAR13 (Fig. 1) with BamHI-digested pDM1. The plasmid pDM2 $(7.06 \mathrm{~kb})$ having the E. coli dnaA gene oriented in the direction of $p \mathrm{~L}$ promoter was selected by its ability to complement $E$. coli danAts 46 mutant at $42^{\circ} \mathrm{C}$.

Transformation and $\lambda \mathbf{P}$ sensitivity of $\boldsymbol{E}$. coli These were done by the procedures exactly as described in the preceding paper (Datta et al., 2005).

Purification of proteins and their functional assays Wild-type DnaA was purified from E. coli 594 ( $\lambda 112$ ) harboring pDM2 containing the wild-type $d n a A$ gene tagged to the $p \mathrm{~L}$ promoter (Fig. 1). The bacteria were grown at $32^{\circ} \mathrm{C}$ to $0.4 \mathrm{OD}_{590}$, induced at $42^{\circ} \mathrm{C}$ for $15 \mathrm{~min}$, and then grown further for $1 \mathrm{~h}$ at $38^{\circ} \mathrm{C}$. The cells were then harvested and used to purify the DnaA protein by the procedure of Sekimizu et al. (1988). The rpl8 DnaA protein was purified from E. coli 594 rpl8 harboring pDMrpl8-1 (Fig. 1) also by the procedure of Sekimizu et al. (1988). During purification, the DnaA containing fractions were monitored by oriC DNA-binding assay as described later. The DnaB protein (this protein will be called as DnaB in the text) was partially ( $>1,000$ fold) purified (through the streptomycin sulphate, ammonium sulphate and DEAE-Cellulose steps) from heat-induced E. coli 594 ( $\lambda 112)$ harboring pSP562 by the method of Reha-Krantz and Hurwitz (1978a), and the fractions containing DnaB were monitored by determining ss-DNA-dependent ATPase activity (Reha-Krantz and Hurwitz 1978b)

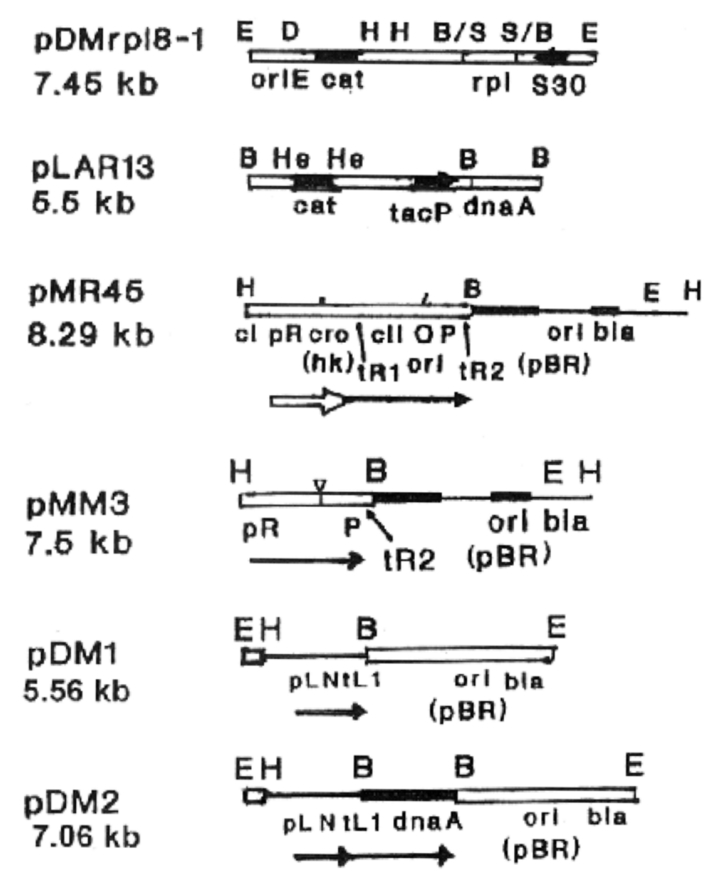

Fig. 1. Maps of different plasmids. Maps of the plasmids are shown in linearized forms nearly to the same scale. Sizes of the plasmids in $\mathrm{kb}$ are indicated by the numbers written below the names of the plasmids at the left. Approximate positions of the restriction enzyme cleavage sites are indicated by the enzyme symbols written above the map and those of different important genes and replication origins by the gene and ori symbols written below the map. The arrows show the directions of promoters. The restriction enzyme symbols: B, BamHI; D, DraI; E, EcoRI; and H, HindIII; S, Sau3AI.

The $\lambda \mathrm{P}$ protein was purified from E. coli rpl8 $(\lambda 112)$ harboring pMM3 (Fig. 1). The bacteria were grown at $32^{\circ} \mathrm{C}$ to $0.4 \mathrm{OD}_{590}$, induced at $42^{\circ} \mathrm{C}$ for $15 \mathrm{~min}$ and then grown for $1 \mathrm{~h}$ at $38^{\circ} \mathrm{C}$. The cells were then harvested. The $\mathrm{P}$ protein was isolated by the procedure of Tsurimoto et al. (1982). The fractions containing $\mathrm{P}$ was monitored by its ability to inhibit the ATPase activity of DnaB in the presence of ss-DNA (Reha-Krantz and Hurwitz, 1978b).

All the three protein preparations (wild-type DnaA, rpl DnaA and P) were more than $90 \%$ homogeneous. Both the purity and molecular weights of all these proteins were checked by SDS polyacrylamide gel electrophoresis (Sambrook et al., 1989).

The binding of DnaA to oriC DNA was measured by the filterbinding method (Fuller and Kornberg, 1983). The reaction mixture contained $40 \mathrm{mM}$ HEPES-KOH (pH 7.6), $150 \mathrm{mM} \mathrm{KCl}, 10 \mathrm{mM}$ Mg-acetate, $2 \mathrm{mM}$ DTT, and $100 \mu \mathrm{g} / \mathrm{ml}$ of BSA, $150 \mathrm{ng}$ of $\left[{ }^{3} \mathrm{H}\right]-$ labeled pTSO200 plasmid DNA and the required amount of DnaA in a total volume of $25 \mu \mathrm{l}$. After incubation for $15 \mathrm{~min}$ at $30^{\circ} \mathrm{C}, 20$ $\mu \mathrm{l}$ of this reaction mixture was filtered on Millipore filter and washed with $40 \mathrm{mM}$ HEPES buffer. The radioactive counts retained on the filter were determined.

The ATP-binding activity of DnaA was measured by the method of Sekimizu et al. (1987). The reaction mixture contained $50 \mathrm{mM}$ HEPES-KOH (pH 8.0), $0.5 \mathrm{mM}$ Mg-acetate, $0.3 \mathrm{mM}$ EDTA, $5 \mathrm{mM}$ DTT, $10 \mathrm{mM}$ ammonium sulphate, $17 \% \mathrm{v} / \mathrm{v}$ glycerol and $0.005 \%$ 
Triton X 100, $0.03 \mu \mathrm{M}\left[\alpha-{ }^{32} \mathrm{P}\right] \mathrm{ATP}$, and DnaA in a total volume of $40 \mu \mathrm{l}$. This mixture was incubated at $0^{\circ} \mathrm{C}$ for $15 \mathrm{~min}$ and then filtered on Millipore filter. In an alternate (modified) method, the reaction mixture (after incubation) was mixed with $160 \mu \mathrm{l}$ cold saturated ammonium sulphate solution and kept on ice for $30 \mathrm{~min}$. The precipitated protein with bound ATP was collected by centrifugation at $12,000 \times g$ for $15 \mathrm{~min}$ at $4^{\circ} \mathrm{C}$ and washed once with $200 \mu \mathrm{l}$ cold saturated ammonium sulphate solution. Finally, the pellet was dissolved in $200 \mu \mathrm{l}$ sterile distilled water, and the radioactive counts were determined. Identical binding results were obtained when $\left[\gamma_{-}{ }^{32} \mathrm{P}\right]$ ATP was used in place of $\left[\alpha{ }^{32} \mathrm{P}\right]$ ATP. This method was adapted from the one developed by Anderson et al. (1971) for the assay of the binding of cyclic AMP to CRP. Following this method, the ATP-DnaA binding results were very reproducible.

Radioactivity and protein measurements Radioactive counts were determined in a Beckman LS 5000CE counter. Protein was quantified by the method of Bradford (1976).

\section{Results}

The oriC DNA-binding activity in wild-type $E$. coli is

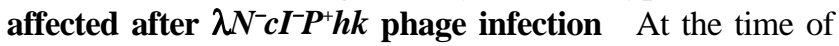
initiation of chromosomal DNA replication in E. coli, the DnaA protein binds to several DnaA-specific conserved 9-mer boxes present within the oriC DNA (Fuller et al., 1984). This DNA-binding activity is an important property of DnaA and can be determined by Millipore filter-binding assay (Fuller and Kornberg, 1983). When a nonpermissive E. coli is infected with the $\lambda N^{-} c \mathrm{I}^{-} P^{+} h k$ phage at a multiplicity of infection (MOI) of 50 or more, the bacterium is killed (Maiti et al., 1991a). To find out if there had been any loss of the oriC DNA-binding activity following challenge with $\mathrm{P}$, we examined the effect of infection by $\lambda N^{-} c \mathrm{I}^{-} P^{+} h k$ phage on the above activity in wild-type $E$. coli. The results presented in Table 1 show that the oriC DNA-binding activity was significantly reduced following infection of E. coli (producing wild-type DnaA) with the above phage. Under identical conditions, however, the oriC DNA-binding activities were not reduced at all in the $\lambda N^{-} c \mathrm{I}^{-} P^{-} h k$ phage-infected wild-type bacteria and in both the above $1 P^{+}$and $1 P^{-}$phage-infected $r p l$ bacteria (Table 1).

The $\lambda P$ protein affects the oriC DNA-binding function of DnaA The reduction in the oriC DNA-binding activity in wild-type $E$. coli by $\lambda N^{-} c \mathrm{I}^{-} P^{+} h k$ phage infection (Table 1) led us to ask as to whether P inhibits the above function of DnaA. To answer this question, we examined the effect of purified $P$ on the oriC DNA-binding activity of purified DnaA. The results presented in Fig. 2 clearly reveal that when $\mathrm{P}$ was added to the reaction mixture before the addition of oriC DNA, the binding of wild-type DnaA to oriC DNA was inhibited, and the amount of inhibition increased with the amount of $\mathrm{P}$ added (curve A). This inhibition reached its
Table 1. Effect of $\lambda N^{-} c \mathrm{I}^{-} h k P^{+}$infection on the oriC DNAbinding activity in wild-type and $r p l$ mutant $E$. coli

\begin{tabular}{lc}
\hline \multicolumn{1}{c}{ E. coli extract } & $\begin{array}{c}\text { OriC DNA-binding activity }^{b} \\
\text { (pmol DNA bound/mg protein) }\end{array}$ \\
\hline 1. Uninfected wild type & $2.15 \pm 0.36$ \\
2. $\lambda N^{-} c \mathrm{I}^{-} h k P^{+}$-infectd wild type & $0.40 \pm 0.11$ \\
3. $\lambda N^{-} c \mathrm{I}^{-} h k P^{-}$-infectd wild type & $2.52 \pm 0.06$ \\
4. Uninfected $r p l 8$ & $1.60 \pm 0.08$ \\
5. $\lambda N^{-} c \mathrm{I}^{-} h k P^{+}$-infectd $r p l 8$ & $1.70 \pm 0.16$ \\
6. $\lambda N^{-} c \mathrm{I}^{-} h k P^{-}$-infectd $r p l 8$ & $2.06 \pm 0.03$ \\
\hline
\end{tabular}

${ }^{a}$ E. coli BR1639 (pALO12) (wild-type dnaA) and E. coli 594 rpl8 (pDMrpl8-1) were grown in TBM (the former in the presence of $2 \mathrm{mM}$ IPTG) both to around $0.5 \mathrm{OD}_{590}$. From each culture, $2 \times 5$ $\mathrm{ml}$ aliquots were separately infected with the two phages, and $1 \times 5 \mathrm{ml}$ aliquots were kept as uninfected control. All the aliquots were grown further for $1 \mathrm{~h}$. The cells were harvested, washed and broken by sonication, and centrifuged at $100,000 \mathrm{~g}$ for 35 min. The supernatants were treated with $0.28 \mathrm{~g} / \mathrm{ml}$ of $\left(\mathrm{NH}_{4}\right)_{2} \mathrm{SO}_{4}$ in cold. The precipitates were collected by centrifugation, dissolved in storage buffer and dialyzed, and used for the DNAbinding assay. The above partial purification eliminated almost all of the non-specific DNA binding activities as shown by the fact that the binding to radioactive oriC DNA was competed with cold oriC DNA but not with cold non oriC DNA.

${ }^{b}$ Results represent the averages of three independent experiments. For other details, see Methods.

maximum at around the $\mathrm{P}: \mathrm{DnaA}$ weight ratio of $1: 1$ (at a subunit molar ratio of $2: 1$; the molecular weights of $\mathrm{P}$ and DnaA are $25.63 \mathrm{kDa}$ and $51.37 \mathrm{kDa}$ respectively). When oriC DNA was added to DnaA prior to the addition of $\mathrm{P}$, there was no such inhibition (curve B). However, under identical conditions, the binding of $r p l$ DnaA to oriC DNA was not inhibited when $\mathrm{P}$ was added to $r p l$ DnaA both before (curve C) and after (curve D) the addition of oriC DNA (Fig. 2). It was found that the PCR amplified 110 bp DNA containing three conserved 9-mer DnaA boxes R2, R3, and R4 from the minimal $245 \mathrm{bp}$ oriC region within the pTSO200 DNA (the minimal 245 bp oriC DNA contains five such DnaA boxes) could compete with radioactively labeled oriC plasmid DNA; while the fragment of pTSO200 DNA that did not contain the 245 bp oriC DNA, did not show any such competition (data not shown). This suggests that the above binding of DnaA was specific for the oriC segment within the pTSO200 DNA.

The $\lambda P$ protein also affects the ATP-binding function of DnaA The DnaA protein binds ATP, and this ATP-DnaA complex is the functional form that is essential for the opening of the 13-mer sequences within the oriC DNA during the initiation of DNA replication (Sekimizu et al., 1987). As P inhibits the interaction of DnaA with oriC DNA (Fig. 2), we also examined the effect of $\mathrm{P}$ on the binding of ATP to DnaA. The results in Table 2 show that when wild-type DnaA was incubated with P and then ATP was added, the binding of this 


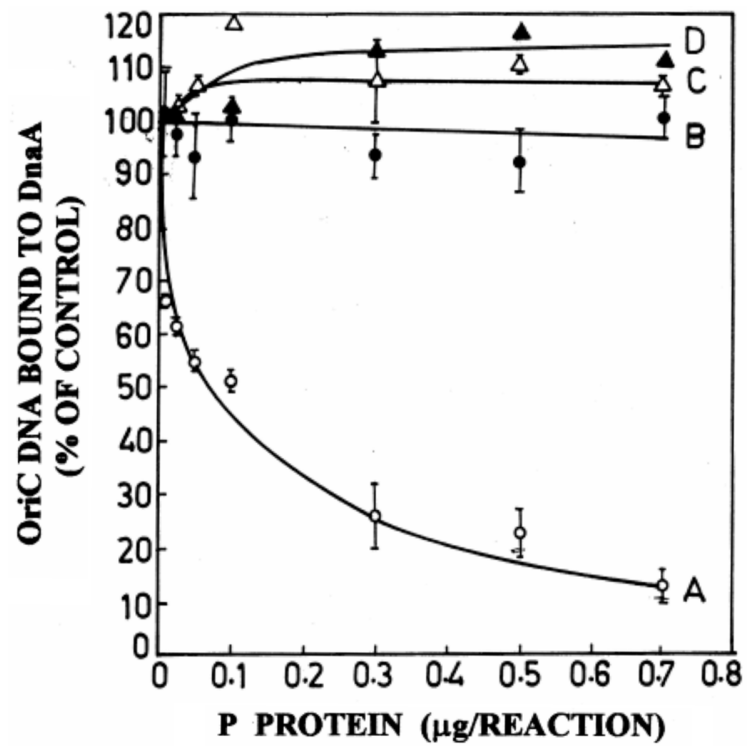

Fig. 2. Effect of $\lambda \mathrm{P}$ protein on the binding of oriC DNA to wild-type and rpl8 DnaAs. The DNA-binding activity of DnaA was assayed as described in Methods. In $A$ and $C$, the reaction mixtures containing $\mathrm{P}$ and DnaA were incubated for $10 \mathrm{~min}$ at $30^{\circ} \mathrm{C}$ and then oriC DNA was added and incubated further for $15 \mathrm{~min}$ at the same temperature. In $B$ and $D$, DnaA was incubated with oriC DNA for 15 min and then $\mathrm{P}$ was added and incubated further for $10 \mathrm{~min}$. The control $(100 \%)$ values for the binding of oriC DNA to wild-type and rpl-type DnaAs were respectively 116 and $107 \mathrm{pmol} / \mathrm{mg}$ of protein. The amounts of DnaA and oriC DNA per reaction were used at $0.7 \mu \mathrm{g}$ and 150 ng respectively (these amounts were determined to be required for maximum binding from saturation experiments). In control experiments, addition of varying amounts of P-storage buffer without $\mathrm{P}$ showed the pattern of binding of oriC DNA to wildtype and $r p l$ DnaAs similar to that in B and D respectively. The results represent the averages of three experiments, and the standard deviations are shown. Curves: $A$ and $B$, wild-type DnaA; and $C$ and $D, r p l$ DnaA. For other details, see Methods.

nucleotide to DnaA was drastically reduced (line 3). However, when DnaA was incubated with ATP and then P was added, the binding of the nucleotide was not affected (line 2). The interaction of ATP with $r p l$ DnaA was not inhibited by $\mathrm{P}$ under any of the above conditions (Table 2, lines 4-6).

\section{$E$. coli dnaAcos mutant is sensitive to $\lambda \boldsymbol{P}$ gene-mediated} killing The DnaAcos protein does not bind ATP but binds to oriC DNA and activates the initiation of DNA replication, though at $43^{\circ} \mathrm{C}$ (Katayama 1994). As the interaction of wildtype DnaA with both oriC DNA and ATP was inhibited by P, we were interested to see if the E. coli dnaAcos mutant is sensitive to $\mathrm{P}$. The results in Table 3 show that the E. coli dnaAcos mutant was killed when challenged with $\mathrm{P}$ by transformation with pMR45. This suggests that $\mathrm{P}$ can interact with the mutationally altered DnaAcos protein (in the absence of ATP binding) and inhibits the binding of latter protein to oriC DNA thereby causing bacterial killing.
Table 2. Effect of the $\lambda \mathrm{P}$ protein on the binding of ATP to DnaA

\begin{tabular}{|c|c|c|c|}
\hline \multirow{2}{*}{ DnaA type $^{a}$} & \multicolumn{2}{|c|}{ Ligand added $^{b}$} & \multirow{2}{*}{$\begin{array}{l}\text { nmol ATP bound } \\
\text { per mg of protein }\end{array}$} \\
\hline & First & Second & \\
\hline \multirow[t]{3}{*}{ Wild type } & ATP & None $^{d}$ & $2.75 \pm 0.05(100)$ \\
\hline & ATP & $\mathrm{P}$ & $2.81 \pm 0.11(102)$ \\
\hline & $\mathrm{P}$ & ATP & $0.28 \pm 0.005$ \\
\hline \multirow[t]{3}{*}{ rpl8 type } & ATP & None $^{d}$ & $1.82 \pm 0.03$ \\
\hline & ATP & $\mathrm{P}$ & $1.86 \pm 0.065(102)$ \\
\hline & $\mathrm{P}$ & ATP & $1.89 \pm 0.21$ \\
\hline
\end{tabular}

${ }^{a}$ Purified wild-type and $r$ pl8 DnaAs and P were used.

${ }^{b}$ After the addition of the first ligand, the reaction mixture was incubated for $15 \mathrm{~min}$ at $0^{\circ} \mathrm{C}$, and then the second ligand was added, and incubated further for $10 \mathrm{~min}$ at $0^{\circ} \mathrm{C}$. The reaction mixture without the second ligand was incubated for $25 \mathrm{~min}$. The reaction mixture was mixed with required volume of cold saturated ammonium sulphate solution, and the protein-bound ATP in the precipitate was determined. The wild- and rpl8-type DnaAs and $\mathrm{P}$ were used at $0.7 \mu \mathrm{g}$ each per reaction and ATP at 0.03 $\mathrm{mM}$.

'The data represent the averages of two independent experiments. The figures in parenthesis indicate $\%$ of control.

${ }^{d}$ These reaction mixtures contained the volume of P-storage buffer without $\mathrm{P}$ that was equal to the volume of $\mathrm{P}$ added to the other reaction mixtures.

For other details, see Methods.

\section{Discussion}

The results presented in this paper show that the bacteriophage $\lambda$ DNA replication protein $\mathrm{P}$ specifically inhibits the binding of oriC DNA and ATP.to wild-type DnaA but not to its $r p l$ mutant form. This suggests that this inhibitory action of $\mathrm{P}$ on the binding of DnaA to oriC DNA and ATP causes a total arrest of host DNA synthesis, which ultimately leads to bacterial death. Thus the bacterial killing induced by $\mathrm{P}$ (which is not dependent on phage DNA replication, Maiti et al., 1991a) differs from that caused by the induction of $\lambda N^{c} \mathrm{cI}$ ts lysogen at $42^{\circ} \mathrm{C}$ that requires phage DNA replication (Sly et al., 1968) and by the Kil protein of $\lambda$, which interacts with certain component(s) of cell envelope (Greer, 1975a; 1975b) and inhibits cell division (Sergueev et al., 2001).

The binding of DnaA to several 9-mer sequences within the oriC region is a prerequisite for the subsequent events that lead to the DNA replication initiation. The ATP-bound form of DnaA bound to oriC DNA helps open the 13-mer AT-rich sequence within this region to form the preprimosome, while the ADP-bound form can also bind to oriC DNA but fails to open the 13-mer AT-rich segment (Sekimizu et al., 1987). Both the expression (Messer and Weigel, 1997) and the activity of DnaA (Katayama et al., 1998; Sekimizu et al., 1987) are regulated in various ways to control its function related to the oriC-dependent initiation of DNA replication. 
Table 3. Effect of the $\lambda P$ gene product on the survival of $E$. coli dnaAcos mutant

\begin{tabular}{lccc}
\hline \multirow{2}{*}{ Bacteria $^{a}$} & & \multicolumn{2}{c}{$\begin{array}{c}\text { Survival after transformation } \\
\text { with different plasmids }\end{array}$} \\
\cline { 2 - 4 } & & Plasmid & \\
& & CFU/mg DNA & $\%$ of Control \\
\hline E. coli rpl8 & pMR45 & $5.5 \times 10^{5}$ & 100 \\
& pMR58 & $4.9 \times 10^{5}$ & 89.1 \\
E. coli 594 & pMR45 & $<6 \times 10^{2}$ & $<0.1$ \\
& pMR58 & $5.2 \times 10^{5}$ & 94.5 \\
E. coli dnaAcos & pMR45 & $<6 \times 10^{2}$ & $<0.1$ \\
& pMR58 & $4.8 \times 10^{5}$ & 87.3 \\
\hline
\end{tabular}

${ }^{a}$ After transformation, E. coli rpl8 and 594 were plated at $37^{\circ} \mathrm{C}$ and dnaAcos at $42^{\circ} \mathrm{C}$.

${ }^{b}$ The plasmid pMR45 is $P^{+}$and pMR58 is $P^{-}$.

For other details, see Methods and Text.

We show that the function of DnaA is negatively regulated also by $\mathrm{P}$ by inhibiting the binding of both oriC DNA (Fig. 2) and ATP (Table 2) to DnaA.

The $\mathrm{P}$ protein inhibits the binding of oriC DNA to wildtype DnaA but not to $r p l$ DnaA (Fig. 2). This inhibitory effect of $\mathrm{P}$ was observed only when this protein was added to wildtype DnaA before the addition of oriC DNA. This suggests that following the binding of oriC DNA with wild-type DnaA or due to the amino acid change(s) caused by the $r p l$ mutation(s), the conformation of DnaA changes to certain form that does not allow its interaction with $\mathrm{P}$. The data in Table 2 show that $\mathrm{P}$ also inhibits the binding of ATP to wildtype DnaA when $\mathrm{P}$ is added to DnaA before the addition of ATP. It was also observed that $\mathrm{P}$ inhibited the binding of oriC DNA to ATP-bound wild-type DnaA (our unpublished data). It is known that the DnaAcos mutant protein does not bind ATP, yet it can bind to oriC DNA and initiate DNA replication in the above mutant E. coli (Katayama, 1994). Our data show that the dnaAcos mutant bacterium is susceptible to P-induced killing (Table 3). If it is assumed that the cos mutant form of DnaA has a conformation similar to that of the ATP-bound form of the wild-type DnaA, then the above data suggest that the ATP-bound wild-type DnaA can bind to P, but following interaction with $\mathrm{P}$, the wild-type DnaA does not bind ATP and/or oriC DNA.

DnaA is made up of 467 amino acid residues and has several functional domains (Sutton and Kaguni, 1997; Messer, 2002). Those domains of DnaA are involved in the binding of this protein to DNA (Roth and Messer, 1995), RepA protein (Sutton and Kaguni, 1995), ATP (Carr and Kaguni, 1996), DnaB (Marszalek et al., 1996), acidic membrane (Garner and Crooke, 1996) and in its self-oligomerization (Weigel et al., 1999). These domains are present in the above order from $C$ to $\mathrm{N}$ termini of the DnaA protein (see Fig. 3). From this study, we define another domain called the P-interaction domain, which overlaps with the RepA protein-binding domain (Fig. 3). This domain of DnaA is flanked by the ATP-binding

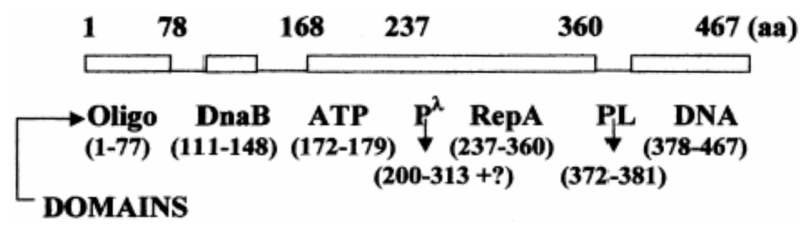

Fig. 3. The domain map of the DnaA protein. Approximate boundaries of different functional domains in the 467-residue DnaA protein are shown. The $\mathrm{P}$ interaction domain defined by the $r p l$ mutations is shown (the boundary of this domain is only approximate, and this is indicated by ? sign). Different domain symbols: Oligomer, protein-protein interaction; DnaB, interaction with DnaB; ATP, binding of ATP; $\mathrm{P}^{\lambda}$, interaction with $\lambda \mathrm{P}$ protein; RepA, interaction with RepA protein; PL, interaction with membrane phospholipid; and DNA, binding of oriC DNA

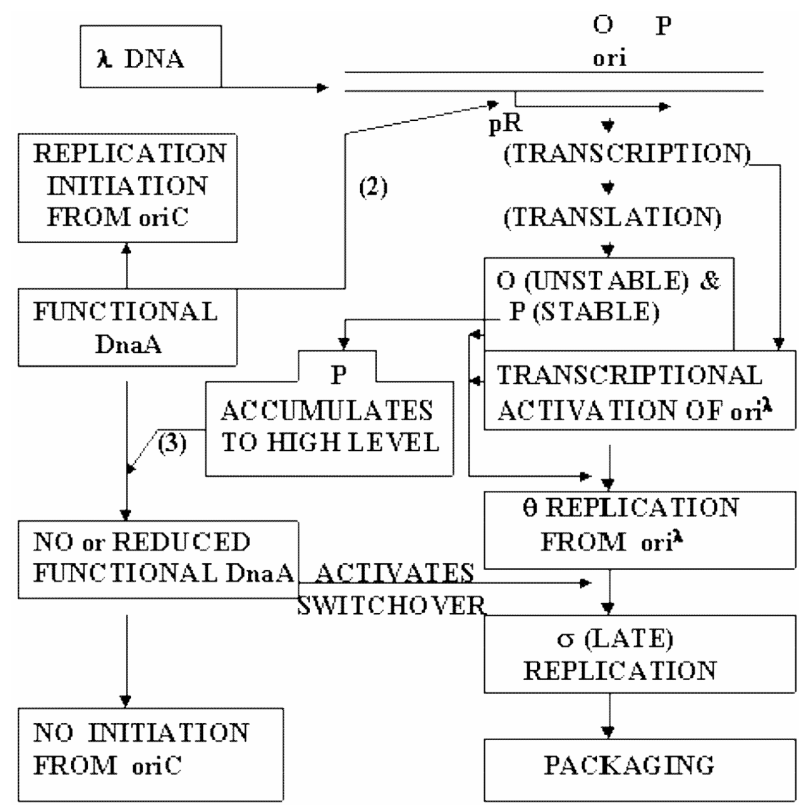

Fig. 4. Proposed model for the P-lethal circuit. (1) Activation of DNA replication initiation from oriC by DnaA; (2) Stimulation of transcription from $p \mathrm{R}$ of $\lambda$ that leads to (a) increased level of expression of $\mathrm{O}$ and $\mathrm{P}$ and (b) transcriptional activation of ori $^{\lambda}$ initiating theta replication; (3) The $\mathrm{P}$ protein at high level, inactivates DnaA, which (a) affects bacterial DNA replication initiation from oriC of $E$. coli and (b) activates the switchover from early (theta) to late (sigma) mode of $\lambda$ DNA replication. For other details, see discussion.

domain at the N-terminal side and the DNA-binding domain at the C-terminal side. This, possibly, explains the fact that the binding of $\mathrm{P}$ to this region of DnaA inhibits the binding of both oriC DNA and ATP to the latter protein. However, the $r p l$ mutational alteration in this domain, which confers on DnaA with its resistance to $\mathrm{P}$ lethality, does not affect the binding of either oriC DNA or ATP to $r p l$ DnaA. The binding stoichiometry of 2 mole of $\mathrm{P}$ with one of DnaA in Fig. 2 may suggest that a dimer of $\mathrm{P}$ (Zylicz et al., 1984) possibly interacts with the above-defined P-interaction domain of 
DnaA and disrupts the conformation/orientation of both the flanking ATP and DNA-binding domains (Erzberger et al., 2002) thereby disallowing the binding of ATP and oriC DNA to DnaA.

It may now be asked as to why the $\mathrm{P}$ protein of $\lambda$ is involved in the inhibitory interaction with DnaA, and whether this interaction is beneficial for the growth and multiplication of $\lambda$. It has been reported by Konopa et al. (2000) that at $43^{\circ} \mathrm{C}$, the $\lambda$ Pts IpiA66 mutant cannot replicate in wild-type $E$. coli but can do so in the E. coli dnaAts 46 mutant. The $\lambda$ DNA replication has been shown to switch quickly from the theta to the sigma mode in the absence of functional DnaA (Konopa et al., 2000; Baranska et al., 2001). This also implies that DnaA possibly inhibits, directly or indirectly, the above switchover process. Therefore, our results along with those of Konopa et al. (2000) suggest that the interaction of P with DnaA has two effects: (a) it inhibits $E$. coli DNA initiation by inhibiting the binding of DnaA to oriC DNA and ATP, and (b) it helps $\lambda$ replication to switchover from the theta to the sigma mode. The former effect appears to be lethal to the host cell, while the latter is beneficial to $\lambda$ growth. DnaA also stimulates the transcription from $p \mathrm{R}$ of $\lambda$ (Szalewaska-Palasz et al., 1998), thereby stimulating the expression of $P$ (and $O$ ) genes and effecting transcriptional activation of ori $^{\lambda}$. The $\mathrm{P}$ protein is stable and is required only during the initiation of theta replication of phage DNA (Klinkert and Klein, 1979), while DnaA inhibits the theta to sigma switchover (Konopa et al., 2000; Baranska et al., 2001). So, in the above background, we propose that the DnaA protein of $E$. coli is used by $\lambda$ for stimulating the initiation of circle to circle replication of its DNA by activating the expression of $\mathrm{P}$ (and $\mathrm{O}$ ) from $p \mathrm{R}$ as well as by increasing the frequency of transcriptional activation of ori $^{\lambda}$ at the early stage of phage growth. At the late stage, the accumulated (stable) P inactivates DnaA to facilitate switchover from the theta to the sigma mode of $\lambda$ DNA replication possibly by reducing the frequencies of both transcription from $p \mathrm{R}$ and transcriptional activation of $o r i^{\lambda}$ (see Fig. 4 for the proposed model). By this process, the DnaA function is inhibited (which is lethal to host), and also the $\mathrm{P}$ protein, which is no longer required during the rolling circle replication of $\lambda$ DNA, is removed or inactivated.

Acknowledgments We thank Drs. A. Kornberg, S. Adhya, D. Chattoraj, M. Ptashne, A. Oka, and T. Katayama for various bacterial, phage and/ or plasmid strains, and P. Parrack for critically reading the manuscript. Expert technical assistance of Mr. N. C. Datta is thankfully acknowledged. This work was supported by financial grants from the Council of Scientific and Industrial Research and the Department of Biotechnology, Govt. of India.

\section{References}

Anderson, W. B., Schneider, A. B., Emmer, M., Perlman, R. L. and Pastan, I. (1971) Purification and properties of cyclic adenosine 3', 5'-monophosphate receptor protein which mediates cyclic adenosine 3', 5'-monophosphate-dependent gene transcription in Escherichia coli. J. Biol. Chem. 246, 59295937.

Baranska, S., Gabig, M., Wegrzyn, A., Konopa, G., HermanAntosiewicz, A., Hernandez, P., Schvartzman, J. B., Helinski, D. R. and Wegrzyn, G. (2001) Regulation of the switch from early to late bacteriophage DNA replication. Microbiol. 147, 535-547.

Bradford, M. (1976) A rapid and sensitive method for the quantitation of microgram quantities of protein utilizing the principle of protein-dye binding. Anal. Biochem. 72, 248-254.

Carr, K. M. and Kaguni, J. M. (1996) The A184V missense mutation of the dnaA5 and dnaA46 alleles confers a defect in ATP binding and thermolability in initiation of Escherichia coli DNA replication. Mol. Microbiol. 20, 1307-1318.

Chattopadhyay, D. J. and Mandal, N. C. (1982) Studies on polylysogens containing $\lambda N^{-} c \mathrm{I}^{-}$prophages. I. Control of synthesis and maintenance of a large number of integrated $\lambda$ genomes. Virology 118, 439-447.

Datta, I., Banik-Maiti, S., Adhikary, L., Sau, S., Das, N. and Mandal, N. C. (2005) The mutation that makes Escherichia coli resistant to $\lambda P$ gene-mediated host lethality is located within the DNA initiator gene dnaA of the bacterium. $J$. Biochem. Mol. Biol. 38, 89-96.

Erzberger, J. P., Pirruccello, M. M. and Berger, J. M. (2002) The structure of bacterial DnaA: implications for general mechanisms underlying DNA replication initiation. EMBO J. 21, 4763- 4773.

Friedman, D. I., Olson, E. R., Georgopoulos, C., Tilly, K., Herskowitz, I. and Banuette, F. (1984) Interactions of bacteriophage and host macromolecules in the growth of bacteriophage $\lambda$. Microbiol. Rev. 45, 299-325.

Fuller, R. and Kornberg, A. (1983) Purified DnaA protein in initiation of replication at the Escherichia coli chromosomal origin of replication. Proc. Natl. Acad. Sci. USA 80, 58175821.

Fuller, R. S., Funnel, B. E. and Kornberg, A. (1984) The DnaA protein complex with the $E$. coli chromosomal replication origin (oriC) and other DNA sites. Cell 38, 889-900.

Furth, M. E. and Wickner, S. H. (1983) Lambda DNA replication; in Lambda II, Hendrix, R. W., Roberts, J. W. and Stahl, F. (eds.), pp. 145-173, Cold Spring Harbor Laboratory Press, New York, USA.

Garner, J. and Crooke, E. (1996) Membrane regulation of the chromosomal replication activity of $E$. coli DnaA requires a discrete site on the protein. EMBO J. 15, 3477-3485.

Georgopoulos, C. and Hohn, B. (1978) Identification of a host protein necessary for bacteriophage morphogenesis the groE gene product. Proc. Natl. Acad. Sci. USA 75, 131-135.

Greer, H. (1975a) The kil gene of bacteriophage $\lambda$. Virology 66, 589-604.

Greer, H. (1975b) Host mutants resistant to phage lambda killing. Virology 66, 605-609.

Katayama, T. (1994) The mutant DnaAcos protein which overinitiates replication of the Escherichia coli chromosome is inert to negative regulation for initiation. J. Biol. Chem. 269, 22075-22079.

Katayama, T., Kubota, T., Kurokawa, K., Crooke, E. and 
Sekimizu, K. (1998) The initiator function of DnaA protein is negatively regulated by the sliding clamp of $E$. coli chromosomal replicase. Cell 94, 61-71.

Kedzierska, B., Glinkowska, M., Iwanicki, A., Obuchowski, M., Sojka, P., Thomas, M. S. and Wegrzyn, G. (2003) Toxicity of the bacteriophage $\lambda$ cII gene product to Escherichia coli arises from inhibition of host cell DNA replication. Virology 313, 622-628.

Klinkert, J. and Klein, A. (1979) Roles of bacteriophage lambda gene products $\mathrm{O}$ and $\mathrm{P}$ during early and late phages of infection cycle. J. Virol. 25, 730-737.

Konopa, G., Baranska, S, Wegrzyn, A. and Wegrzyn, G. (2000) Bacteriophage and host mutants causing the rolling circle lambda DNA replication early after infection. FEBS Letts. 472, 217-220.

Lobner-Olesen, A., Skarstad, K., Hansen, F. G., von Meyenberg, K. and Boye, E. (1989) The DnaA protein determines the initiation mass of Escherichia coli K-12. Cell 57, 881-889.

Maiti, S., Das, B. and Mandal, N. C. (1991b) Isolation and preliminary characterization of Escherichia coli mutants resistant to lethal action of the bacteriophage $\lambda P$ gene. Virology 182, 351-352.

Maiti, S. Mukhopadhyay, M. and Mandal, N. C. (1991a) Bacteriophage $\lambda P$ gene shows host killing which is not dependent on $\lambda$ DNA replication. Virology 182, 324-335.

Marszalek, J., Zhang, W., Hupp, T. R., Margulies, C., Carr, K. M., Cherry, S. and Kaguni, J. M. (1996) Domains of DnaA protein involved in interaction with DnaB protein, and in unwinding the Escherichia coli chromosomal origin. J. Biol. Chem. 271, 18535-18542.

Messer, W. (2002) The bacterial replication initiator DnaA. DnaA and $o r i C$, the bacterial mode to initiate DNA replication. FEMS Microbiol. Rev. 26, 355-374.

Messer, W. and Weigel, C. (1997) DnaA initiator is also a transcription factor. Mol. Microbiol. 24, 1-6.

Oka, A., Sugimoto, K., Takanami, M. and Hirota, Y. (1980) Replication origin of the Escherichia coli $\mathrm{K}-12$ chromosome: The size and structure of the minimum DNA segment carrying the information for autonomous replication. Mol. Gen. Genet. 178, 9-20.

Reha-Krantz, L. J. and Hurwitz, J. (1978a) The dnaB gene product of Escherichia coli. I. Purification, homogeneity and physical properties. J. Biol. Chem. 253, 4043-4050.
Reha-Krantz, L. J. Hurwitz, J. (1978b) The dnaB gene product of Escherichia coli. II. Single-stranded DNA-dependent ribonucleoside triphosphatase activity. J. Biol. Chem. 253, 4051-4057.

Roth, A. and Messer, W. (1995) The DNA binding domain of the initiator protein DnaA. EMBO J. 14, 2106-2111.

Sambrook, J, Fritsch, E. F. and Maniatis, T. (1989) Molecular Cloning: A laboratory Manual, 2nd ed. Cold Spring Harbor Laboratory Press, New York, USA.

Sekimizu, K., Bramhill, D. and Kornberg, A. (1987) ATP activates DnaA protein in initiating replication of plasmids bearing the origin of the E. coli chromosome. Cell 50, 259-265.

Sekimizu, K., Yung, B. Y. and Kornberg, A. (1988) The DnaA protein of Escherichia coli: Abundance, improved purification, and membrane binding. J. Biol. Chem. 263, 7136-7140.

Sergueev, K., Yu, D., Austin, S. and Court, D. (2001) Cell toxicity caused by products of the $p L$ operon of bacteriophage lambda. Gene 272, 227-235.

Sly, W. S., Eisen, H. and Siminovitch, S. (1968) Host survival following infection with or induction of bacteriophage lambda mutants. Virology 34, 112-127.

Sutton, M. D. and Kaguni, J. M. (1995) Novel alleles of the Escherichia coli dnaA gene are defective in replication of pSC101 but not of oriC. J. Bacterol. 177, 6657-6665.

Sutton, M. D. Kaguni, J. M. (1997) The Escherichia coli dnaA gene: Four functional domains. J. Mol. Biol. 274, 546-561.

Szalewaska-Palasz, A., Wegrzyn, A., Blaszczak, A., Taylor, K. and Wegrzyn, G. (1998) DnaA-stimulated transcriptional activation of ori $^{\lambda}$ : Escherichia coli RNA polymerase a subunit as a transcriptional activator contact site. Proc. Natl. Acad. Sci. USA 95, 4241-4246.

Tsurimoto, T., Hase, T., Matsubara, H. and Matsubara, K. (1982) Bacteriophage $\lambda$ initiators: Preparation from a strain that overproduces the $\mathrm{O}$ and $\mathrm{P}$ proteins. Mol. Gen. Genet. 187, 7986.

Weigel, C., Schimdt, A., Seitz, H., Tungler, D., Welzeck, M. and Messer, W. (1999) The N-terminus promotes oligomerization of the Escherichia coli initiator protein DnaA. Mol. Microbiol. 34, 53-66.

Zylicz M., Gorska I., Taylor K. and Georgopoulos C. (1984) Bacteriophage $\lambda$ replication proteins: Formation of a mixed oligomer and binding to the origin of $\lambda$ DNA. Mol Gen Genet 196, 401-406. 